\title{
Of Mice and Men Gaze at Evil
}

\author{
Amir Abbas Moslemi \\ PO BOX 16765-3367, Tehran, Iran
}

a.a.moslemi@gmail.com

Keywords: Episteme, problem of evil, mouse or rat, carceral archeology, Confucian philosophy

\begin{abstract}
Ezra Pound's Shi-Shu: Rats is read Foucauldianly to instantiate an interaction between Confucianism and Western schools of thought in response to the problem of evil. There is a review of Leibniz's theodicy to clear up confusion, and also to pave the way for a succession of readings of a number of philosophers like Hume and James - foregrounding epistemic inclination of poets like Pope, Wordsworth and Burns. 'Accidentality' and 'essentiality' are key philosophic terms, without which this problem cannot hold its logical structure, especially in terms of an answer. Epistemopolitical 'docility' and literal 'decency' are employed together for the first time to be reintroducing ancient relationship between cruel politicians and carceral system. Utopia is taken as a mere dream so that 'the problem' would tend to keep its identity. What is new in this paper is a 'gaze'-wise trace of mice in literature supporting the problem of evil in philosophy, based on an actual political background, within a broad sociological realm.
\end{abstract}

"The playgue will be soon over, rats! Let sin!” [1]

"Bus stop rat bag, ha ha charade you are... You house proud town mouse, ha ha charade you are"

\section{Introduction}

Waters" "house proud town mouse" [2] points to an evil in a system of government. Is "growing untaxed" [3], an absence of evil? Rats, sin and plague may recall an idea of Herrick that "evil no nature hath; the loss of good is that which gives to sin a livelihood" [4]. Another example of evil in classic literature is Shakespeare's "How now, a rat? Dead for a ducat, dead!". Evil of the politician in the house Waters criticizes, of Polonius which makes Hamlet stab his sword amidst the arras, of the rats sinning within the plague and of much more instances, is the son et lumière of countless thinkers, narrating indecency and indiscretion of mankind; "the evil that men do lives after them".

Epistemologically speaking, one seems to hold a prior perspective, to make judgment about the co-existence of probable rational reasons, with multifarious concepts of all-goodness, than to state or regard what God's will-wise antecedents are. There is a wide choice of entrances to the old problem of evil, yet to portray the vastness of its importance within the science of logic, this introduction takes a classic approach to broach the subject. Recuperating from ambiguity, Marilyn McCord Adams sums up the opening of "the so-called 'logical' problem of evil" as

(I) God exists, and is essentially omnipotent and perfectly good; and

(II) evil exists,

combine with the following plausible attribute analysis:

(P1) a perfectly good being would always eliminate evil in so far as it could;

(P2) an omniscient being would know all about evils; and

(P3) there are no limits to what an omniscient being can do, 
to form an inconsistent quintet, so that the conjunction of any four entails the denial of the fifth; most notably the conjunction of (P1) - (P2) with either of (I) or (II) entails that the other is false [5].

It is said that some Greek philosophers believed in a lack of any real evil when things are looked at 'sub specie aeternitatis' [6]. Other answers to the problem of evil are given, yet denied, accepted or are still under close assessment by logicians and philosophers. What is based on here is the most famous of all - the one Leibniz develops, prior to Holocaust which begot some theologians reweigh the problem of evil.

Theodicy tries to respond the question why a good God should let evil manifest at all. The semantic of possible worlds, rooted in ontological desire to create "the best of all possible worlds" is a contemporary semantic, accepting the possibility of a world with its maximal consistency in its state of affairs. To put it simply, Leibniz's BPW seeks for the composability of two reasons. Elimination of all instances of evil is not necessary if one seeks for a perfect good God. "O, yet we trust that somehow good will be the final goal of ill" [7]. Standing against Spinoza and Descartes, Leibniz develops a cosmological argument which is deeply rooted in his own version of ontology. Schopenhauer finds this world, "the worst of all possible worlds", which in turn, is "a standing objection to the existence of a beneficent Creator", whereas Leibniz's BPW is based on his "metaphysical optimism", which distinguishes the "moral speaking" from the "absolute speaking". Three types of evil, Leibniz differentiates, in his Theodicy are, metaphysical, physical and moral. "Metaphysical evil consists in mere imperfection, physical evil in suffering, and moral evil in sin" [8].

To state clearly the objectives of this paper, one ought to say that nothing is at stake but to find the lost pieces of the puzzle. As Confucius is one of the pillars of Chinese civilization and Plato has always played the same role in the Greek one - considering the post-structuralist approach of Foucault, this paper seeks to portray the process of constructing new cultures based on the ancient ones, both literally and philosophically.

\section{Gaze and Evil}

The control of 'experts' exercised by modern institutions since the enlightenment, is one of the major libertarian distrusts Foucault initiates in The Birth of Clinic, the subtitle of which reads An Archeology of Medical Perception. He tries to find a reason for "servitude, the worst of ills" [9]. Foucault, the philosopher and historian of thought, takes 'archeology' as an analytical designation of conditions, essential for a system of thought to be created, while imposing its own authority. 'Historical unconscious' of a period in which a system of thought is given, or its 'episteme' or 'archive' is in the center of Foucault's studies, as he emphasizes that the rules underpinning these systems of thoughts, cannot help jettisoning their transparency even to those employing them from time to time.

The Birth of Clinic is an attack on the modern medicine - in especial its institutions and procedures which are rooted in bureaucracy of the hospitals, schools, prisons and the military, assuming that 'clinic' is notably taken as 'teaching hospitals'. Clinic in this sense is what Milton states as "evils which our own misdeeds have wrought" [10]. The result is the docility of the selves in the modern world. Foucault fought his life to paraphrase this docility into which selves are rendered; yoking discipline and docility in terms of cause and effect, "thus discipline produces subjected and practiced bodies, "docile bodies" [11]. To open The Clinic, he writes, "This book is about space, about language and about death. It's about the act of seeing, the gaze" [12]. Provocative 'regard médical' is reiterated throughout the whole text as though, the reader might connote other inciting concepts, like 'medical perception', 'medical regard', 'medical gaze' or any reading which might lead to a synthesis or unification of the function of a subject. Sartrean conceptualization of 'the look' is evolved in the Clinic to focus on a relative power-oriented discussion, in his study of the Benthamian 'panapticon', and then later in Discipline and 
Punishment [13]. This subject is again that very 'author', thinker or a thinking mind that is elaborated in $Q u^{\prime} E s t-c e$ Qu'Un Auteur as a response to the Death of the Author by Barthes, approximately six years after the publication of The Clinic. The evil of illness, both mental and physical, is archeologically assessed to underpin a pair of structures; first, underlying a linguistic modern practice of medicine and second, a conceptual practice of one. Again and again, an elimination of the subject as the center of historical and philosophical analysis pushes the book forward, maintaining a history and philosophy of science which in turn evolves the creation of Foucault's historiography regarding modernist literature. From historiography to historiography, Foucault proceeds, creating a birth of clinic, a birth of prison and a birth of sexuality to portray a guidance towards the Nietzschean debt he has, liberating the mob out of its alien decency through episteme, its docility, its yoke.

Decent powerful guards are all alike, every docile powerless prisoner is made carceral in his own way, an evil-wise post-truth episteme, one might call it. Day in day out, Foucault gets back to nomadology, processing the carceral inquiry he has developed [14]. If one attempts to ascend an etymological step, he will end in descending to the root of "deceere to be fitting", not just within the entry of 'decent' but also for 'docile' [15]. "Le lyrisme de la marginalité peut bien s'enchanter de l'image du " horî 'a-loi », grand nomade social qui rôde aux confins de l'ordre docile et apeuré" [16]; "The lyricism of marginality may find inspiration in the image of the 'outlaw', the greatest social nomad, who prowls on the confines of a docile" (Emphasis Mine). "Evil is not a quality of things as such. It is a quality of our relation to them" [17]. The evil embedded within the power relations and/to knowledge, subject(s) and object(s), subjects and subject(s), prisons, clinics and causes alike - which create the prowling state, for the one who seeks to escape from this situation to another, is rooted in ethical issues, not nature. As a source of positive values, power is itself both repressive and creative, even dangerous [5]. The connection between evil and clinic or prison remains dynamic, all the way the oppressed seeks escape. Evil spreads among people in the form of natural disasters besides the devilish behavior of the people themselves. Throughout The Birth of Prison people are subjects who at times admire the reverse of a blessing. "And there is something decent in the universe (Emphasis Mine) /If I can feel all this, dicto millesimo" (Emphasis Original) [18].

\section{Confucianism and Evil}

Shi-Shu: Rats embraces unique references to the foregoing discourse. What Pound would have excelled to translate, hadn't he wished to be in the same boat as the Chinese common people? He might have read a handful of previous translations like those of James Legge, William Jennings, Arthur Waley, Bernard Karlgren and the list goes on. Pound's priority might be his own being a poet. With regards to verse translation, a poet's carte blanche seems to be much more bona fide than a mere translator, particularly when the source is ingrained not only in poetic realm but also in a philosophical reference to Confucian scripture. The $113^{\text {th }}$ poem from The Book of Songs, Shishu, is a folk song compiled most probably by Confucius himself from among the common people of China, back in Zhou dynasty [19]. In its Chinese version, the song is made up of 3 stanzas. Each stanza has 8 lines and each line consists of 4 characters. The poem is about the cruelty of politicians in power. Metaphorical sense of mice is preferred to its literal meaning since by taking mice as real ones, too humanistic the whole attitude serves. Non-figuratively speaking, cleanliness is a biological feature of mice. Let's forget about their association with plague, which is believed to be due to a lack of human related hygiene. Rats are not pure evil. Humans are not pure evil, too. "They could never in such a Utopian State feel any other ills than those which arise from bodily sickness" [20]. Mice or rats are not new to earth. They might have a history even before the existence of men on earth. It is their right to be fed by nature on their habitat.

We have never grounds for complaint if the metaphorical mice are not adhering to diabolical ideals. The non-literal aspect is less humanistic, but still never totally free from humanism. There is 
a slim chance of proving pound's interest in initiating a Confucian humanist discourse based on Confucian doctrines and Western philosophical traditions. The world of nature preserves its partnership with human beings in the non-figurative sense, yet by casting more light on the metaphorical sense, we give the poem an opportunity to create an atmosphere in which the individual's moral will encounters the problem of evil. Back to Confucius who is reported to have noted "attack the evil that is within yourself, rather than attacking the evil that is in others" [21], one feels that politicians, no matter how high or low their positions are, are again in possession of a sort of right to gobble the poor farmer's millet. Liberally, “...for Confucian thinkers, evil has no existence or reality independent from goodness" [22]. Living before Plato, Confucius - thinking on evil, seems to be Platonic. Within the literal reading, rats are not pure evil, yet at least virtuous to their own selves, also metaphorical politicians are not pure evil to themselves since they are accumulating wealth, if not for the farmers but then for themselves. The one who discerns this notion is John Steinbeck. There are a lot of images, words and literal references for a novelist to be inspired by, yet he finds himself interested in Robert Burns' To a Mouse. Not being purely evil, this mouse lives under a partial attitude towards the problem of evil. Unlike Pound's mouse, Burns' is closer to Platonic literature of Alexander Pope who formulates "All partial evil, universal good; / And, spite of pride, in erring reason's spite, / One truth is clear, Whatever is, is right." [23]. Pope, Burns, Confucius and those who believe this partiality is correct are to a great degree in accordance with Plato who on the contrary to Aristotle, philosophizes on the 'privative evil'. Within this philosophical viewpoint, it is maintained "variously that God cannot overcome certain natural necessities (Like Plato's Demiurge)" [5]. Differentiating between 'accidentality' and 'essentiality', (im)perfection of an existent highlights the logical 'complete cause'. If perfection of A is dependent on privation of $\mathrm{B}$, this privation is a part of the 'complete cause' of that very perfection. Therefore, this so-called evil is considered good for A, but not B. The same abstraction is deduced for the imperfection of an existent. Thus all existence is good, yet in the sense that it causes a privation, the abstracted evil results an 'essential good' and an 'accidental evil'. What is said is totally different from what Aristotle philosophizes. Aristotle believes that first, regarding quality, the number of evil(s), is so much less than the number of $\operatorname{good}(\mathrm{s})-\operatorname{good} \operatorname{existent}(\mathrm{s})$ and evil existent(s), yet evil exists. Second, there has never been any way for the non-existence of evil and third, these few evils are the source of perfection for others. The complaint of the poem's farmer is not a new one. Job had difficulty with the evil in the Bible and Pound Keeps recurring his mice imagery, as in Lustra.

Apart from philosophical doctrines, abundance of mice on a white sheet of paper juxtaposes an imagery of resourcefulness to the linguistic creativity concerning notions such as omnipresence. The structural morphology of the image, shares a conspicuous congruousness, excluding any doubtful ambience, hence foreordaining solidarity of the words on the page, as if mice are on the field. Words as rats, scattered on a sheet of white paper, are the audience to the poet, which receive a sharp reprimand. Words as soldiers of language are betraying the poet as rats, discontinuing the process of farming to the farmer; "A language without words, possessing an entirely new syntax, to be formed; a language that didn't own its truth to speech but to the gaze alone" [12].

We approve of virtue of the good and wickedness of the bad or evil, for example goodness of justice or badness of cruelty. There is the 'complete cause' of good whenever we have justice, likewise we have the complete cause of evil when we have injustice. Hence, if mice are metaphor for government soldiers or agents, there will be no rational explanation for their cruel deeds, so that any rationalization would be a prelude to sophistry. A fair interpretation of "LoKuo" [3] would be a utopia. (Chrono)logically, since Confucius (551-479 BC) used to live prior to Plato (423-347 BC), it is expected that Plato is influenced by Confucius, yet what is brought here serves as an introduction to a contrary proposition. 


\section{Episteme and Evil}

Job's "And why from the womb Hast Thou brought me forth? I expire, and the eye does not see me", or/and "I wish I were dead", can be considered as complaint(s) [24]. One wonders whether it would be a much virtuous creation incase evil and imperfection - either due to the effects of natural elements such as flood, illness, or because of human malefactors such as crime or injustice, were never present within any cosmology. Foucault believes that the intellectuals, thinkers, poets and those who are assessing an issue professionally, might not be aware of the rules which undergird the whole system of thought in which they are thinking, thus Job is airing his grievance, yet not Alexander Pope. The amount of partiality Pope bestows, is even more when Robert Burns, conferred with wisdom, addresses a mouse. Whether the ordering of the cosmos is wise or not, other related issues, are open to cosmological discussions. Burn's advice to mice is devoid of a hindsight vanity; "foresight may be vain" [25]. Pope's final line is comparable to Dryden's in Edipus, when he just opens the first scene of the third act, "Whatever is, is in its causes just". Also, the rupture Burns employs in the $18^{\text {th }}$ century, is comparable to the one Pound uses in $20^{\text {th }}$ century. "Small, crafty, cowering, timid little beast/ Oh, what a panic is in your little breast", opens the poem To a Mouse, with the penultimate stanza, "The best laid schemes o' mice an' men/ Gang aft agley", which inspired Steinbeck's of Mice and Men. Burns seems to be preferring sympathy to complaint. That we are interfering their realm as intruders, now and then, or that mice are not pure evil, is rendered into, "What then? poor beastie, thou maun live!" [25]. Burns doesn't want the mouse to "lay off" as Pound does. This shift in attitude is believed to be a shift in episteme by Foucault, representing another form of underpinning of a linguistic system. What lies in between is of Wordsworth, differentiating Loving and Liking in Addressed to a Child in $19^{\text {th }}$ century, "Long may you love your pensioner mouse, / Though one of a tribe that torment the house: / Nor dislike for her cruel sport the cat, / Deadly foe both of mouse and rat" [26]. Regarding Burns and Pound, Wordsworth stands in between chronologically, while the shift of episteme has not taken place yet. The perspective Wordsworth has towards the mouse, is in the proximity of the one Burns shares. Still among the-love-boat rather than the-like-road, the mouse dwells, the poet suggests, "Though one of a tribe that torment the house". Epistemic shift of Foucault's example of the clinic takes place within 35 years, yet, after a couple of centuries, Wordsworth still remains attached to the former cycle of the 'archive', in this imagery. Although there is difference between 35 years and a couple of centuries, the thing at stake is the vey shift of episteme which takes place covertly to the thinker(s), in spite of the expertise they are saturated with, either due to the talent or craftsmanship they have exercised.

Taking Confucius for granted, Burns and Leibniz are both $18^{\text {th }}$ century writers. Foucault mentions Leibniz when he is theorizing on the 'docility' [27]. From Little things and creatures to ourselves, little humans, "Christian training", "scholastic pedagogy" and a notable methodology, Foucault follows to connect little things to docility. Burns burns, learning himself burning the house of a little mouse unintentionally. It is believed that such a happening actually happened to Burns, when by coincidence the horse-drawn hoe of Jethro Tull - the reformist from whom the band derived its name, was just nearly an at hand invention of the time. The shift of episteme, here, from $18^{\text {th }}$ century to $20^{\text {th }}$, just as an instance, Foucault points out, is rooted in 'epistemological unconscious', tied to ontological and also cosmological consciousness. Indeed, Bachelard and Althusser are a couple of sources Foucault is inspired by.

\section{Conclusions}

For those cliché readers who think that the main conclusions are only those that can be drawn from research results avoiding references, it is essential to emphasize on the lack of any unanimous given logical response to the problem of evil, at least up to the moment. It is called the problem of evil because it is a 'problem', "le problème", as Foucault goes on. 
It is interesting to keep in mind David Hume's summary of the problem of evil when he writes, "Epicurus's old questions have still not been answered. Is he willing to prevent evil, but not able? Then he is impotent. Is he able but not willing? Then he is malevolent. Is he both able and willing? Then where does evil come from?" [28]. J. L. Mackie also believes that the gist of Pope's discussion leaves the poet nothing yet a vociferous opponent of the existence of evil [29]. Logically speaking, Pope regains consistency by omitting a premise, hence, the denial of the existence of evil. Job and Pound are not tending to do the same. They mention it and even complain. Pound's use of the mouse or rat is not accidental throughout his writings. "Life" and "the field mouse" are given a perfect imagery to discuss in Lustra. For Burns, either we are carrying a parasite as in To a Louse, or counting too much on our future as in To a Mouse, there exists the evil. To choose Pope or Pound, is up to the reader. William James does not hesitate to summarize the whole idea as "to accept, along with the super human consciousness, the notion that it is not all embracing, the notion, in other words, that there is a God, but that he is finite, either in power or in knowledge, or in both at once [30]. Altogether, the problem remains a problem, Foucault writes, not because it is related to evil but because it is a problem. Attacking Descartes and Hegel, Foucault asks "Quelle est la réponse à la question? Le problème" [31]; "What is the answer to the question? The problem". Not being able to clean this mess, the moan would go on forever; "endless moan" [3]. Yet, there exists a much better solution; the retreat. Escaping to isolation can also be the last resort. Pound is "about ready to go / to Lo Kuo" [3] happily, since he knows that Lo Kuo has got "good earth / where we can earn our worth" [3]. How painful it is when the last chance of an intellectual to get rid of a cruel system is always to escape, not to be yoked under a so-called docility. Running away to "happy, happy land, Lo Kuo" [3], at last, alas, might bring happiness.

\section{References}

[1] J. Joyce, Finnegans Wake, Penguin Classics, 1999.

[2] Information on http://rogerwaters.com/.

[3] Information on http://poetrynook.com/poem/shi-shu-rats.

[4] R. Herrick et al., The Hesperides and Noble Numbers, G. Routledge \& Sons; E.P. Dutton \& Co., London; New York, 1905.

[5] E. Craig, The Shorter Routledge Encyclopedia of Philosophy, Routledge, London, 2012.

[6] F. Copleston, A history of philosophy. Greece and Rome, Vol. 1, Continuum, London, 2006.

[7] A.T. Tennyson, The poetical works of Alfred Tennyson, Poet Laureate, Scholarly Publishing Office, University of Michigan Harper \& Brothers Publishers, U.S.A.; New York.

[8] F.C. Copleston, A history of philosophy, Vol. 4, Continuum, London; New York, 2003.

[9] W. Cowper, H. Stebbing, G.B. Andreini, The complete poetical works of William Cowper, esq. : including the hymns and translations from Madame Guion, Milton, etc., and Adam ; a sacred drama ; from the Italian of Gio. Battista Andreini, with a memoir of the author, D. Appleton \& Co., New York, 1843.

[10] J. Milton, M.H. Nicolson, Milton: poems and selected prose, Bantam Books, Toronto, 1969.

[11] M. Foucault, A. Sheridan, Discipline and punish the birth of the prison, Vintage Books, New York, NY, 1995.

[12] M. Foucault, The birth of the clinic: an archaeology of medical perception, Routledge, London, 2010.

[13] J.-P. Sartre, Being and nothingness: an essay on phenomenological ontology, Routledge, London, 2010. 
[14] A.A. Moslemi, Nomadologic Ulysses: Pounding Overseas, International Letters of Social and Humanistic Sciences, 59 (2015) 138-145.

[15] Information on https://www.merriam-webster.com/.

[16] M. Foucault, Surveiller et punir: naissance de la prison, Gallimard, Paris, 1975.

[17] W. Lippmann, A preface to morals, Transaction Books, New Brunswick, New Jersey, 1989.

[18] E. Pound, The cantos of Ezra Pound, New Directions, New York, 1998.

[19] A. Waley, The book of songs, Routledge, London; New York, 2011.

[20] D. Hume, S. Copley, A. Edgar, Selected Essays, OUP Oxford, 2008.

[21] J. Legge, The Analects of Confucius, Floating Press, 2010.

[22] Information on www.patheos.com/.

[23] A. Pope, Essay on Man and Other Poems, Dover Publications, 2012.

[24] T.B.T. Ministry, J.A. Halseth, J.N. Darby, W. Whittingham, M. Coverdale, C. Goodman, A. Gilby, T. Sampson, W. Cole, K. James, English Parallel Bible: Darby 1890 - Geneva 1560 King James 1611, TruthBeTold Ministry, 2017.

[25] Information on https:/www.poetrynook.com/poem/mouse-turning-her-nest-plough.

[26] W. Wordsworth, The Collected Poems of William Wordsworth, Wordsworth Editions, 1994.

[27] M. Foucault, P. Rabinow, The Foucault Reader, Penguin Books, 1991.

[28] D. Hume, Dialogues Concerning Natural Religion, Dover Publications, 2013.

[29] J.L. MacKie, The Miracle of Theism: Arguments for and Against the Existence of God, Clarendon Press, 1982.

[30] W. James, A Pluralistic Universe: Hibbert Lectures at Manchester College on the Present Situation in Philosophy, Floating Press, 2012.

[31] M. Foucault, Dits et écrits: 1954-1988, Editions Gallimard, 1994. 